Conference proceedings $2^{\text {nd }}$ and $3^{\text {rd }}$ Regional Innovation \& Entrepreneurship Conference

\title{
University Business Cooperation: Results of International Student Projects
}

\section{Tom R. Sonntag}

Saxion University of Applied Sciences

\author{
Bart S. Schroten
}

Saxion University of Applied Sciences

\section{Frederique Verburg}

Saxion University of Applied Sciences

\section{Jacques C. Bazen}

Saxion University of Applied Sciences

Abstract: Throughout Europe universities are opening up more and more to society, as part of the ideas of a "third mission of universities" suggested by Etzkowitz \& Leydesdorff in their triple helix model. Part of this is the increasing attention for university - business relations and the emergence of more and more practical student business projects. Whereas the effects of such projects on the learning results of students are well researched, the effects of such projects on the companies appears to be under researched and fuzzy. This article is a case study about measuring the results of a yearly recurring international university - business student cooperation project. The project consists of students working together in international teams to solve a business problem for a company. This article provides a methodology and an attempt to measure the impact of such projects on companies. 
Conference proceedings $2^{\text {nd }}$ and $3^{\text {rd }}$ Regional Innovation \& Entrepreneurship Conference

Keywords: International business, project based education, international cooperation, university-business cooperation, impact study

\section{Introduction}

Companies and universities are increasingly working together (Pavlin, Kesting, \& Baaken, 2016). Etzkowitz \& Leydesdorff (2000) described this tendency with their Triple Helix Model, a model that was used in the development of the case study described in this article. University Business cooperation can take of course many shapes and forms, but in this study, the authors focus on university - business cooperation projects in the form of university - business student projects. In this particular form of cooperation, companies are using the knowledge and work of the students for solving their problems and/or creating new business opportunities. Universities on the other hand change their teaching models or sometimes even their curriculum to support these activities (Johnson, Johnson, \& Smith, 2007). In a metaanalysis of studies dealing with the effects of face to face collaborative learning, Kyndt et al. (2013) found that the majority of studies pointed towards a positive effect of learning and results of especially face to face collaboration projects. The relation is still significant, even when controlled for culture (Western / nonWestern). Even though the effects of university business cooperation in the form of student projects is well researched in terms of learning outcomes and results for participating students (Kyndt et al., 2013), the effects of such cooperation project for companies on the other hand are somewhat under researched. Even an extensive European Union report, written by Davey et al. (2011) about university - business cooperation contains only very limited information about the effects of this cooperation for businesses. Even for university staff with a large experience in university - business cooperation projects, still a significant amount of their time is spent on convincing companies to work with students. An example of this is the following quote from an interview with prof. Mikko Koria of Aalto Business School in Finland, with years of experience in university - business cooperation projects, in the Science - Business report of Edmondson et al. (2012):

"It takes a lot of work to convince companies they get benefits from working with students. I spend 20 to 30 per cent of my time setting up projects with companies". 
Conference proceedings $2^{\text {nd }}$ and $3^{\text {rd }}$ Regional Innovation \& Entrepreneurship Conference

This article is about a case study of a successful yearly university business student cooperation project, the so-called Autumn School. The Autumn School is an international program which provides a rich learning context for students from Russia and the Netherlands, in order to help them to execute an assignment for a Small and Medium Sized Company, preferably in the sphere of technology. The Autumn School is a collaboration between the World Trade Center Twente, Lomonosov Moscow State University and Saxion University of Applied Sciences. More about the program itself and the model as well as the learning effects for students in participating in this project can be found in previous work of the authors (Bazen \& Petrova, 2013, 2014). Within the Autumn School, students from the Netherlands and Russia work together in a group of mixed nationalities, on an assignment of a company. The company can be either from Russia or from Western Europe and is looking for possibilities to expand or start operations in the other region. The assignment for the students is to do an in-depth analysis of either the Russian, or most important EU markets ${ }^{6}$.

The first edition of the Autumn Business School took place in 2013. The main assignment was for a metal company from the Netherlands who wanted to start operations on the Russian market, the company already did some preliminary work and the students were asked to build further upon this. In 2014 the second edition took place, students developed a plan for a transportation materials producer from The Netherlands, to become active in Russia. The third edition took place in 2015 with three companies participating, one Dutch company that wished to go to Russia and two Russian companies that wanted to enter the European market .

Following the earlier mentioned observation that the effects of this specific type of university - business cooperation projects is well researched for learning effects on participating students, but under researched in terms of effects on companies, this study will describe and analyse the follow up from companies based on the recommendations of the students.

This study therefore contains a description of what the companies have learned, if the companies have taken any actions, and if so, which actions the companies have taken.

${ }^{6}$ See also: http://www.autumnbusinessschool.org 
Conference proceedings $2^{\text {nd }}$ and $3^{\text {rd }}$ Regional Innovation \& Entrepreneurship Conference

\section{Research design and research methodology}

The main question for this article is: "What value is added for companies by involving students in researching international business opportunities and advising in international business strategies?"

So far 5 companies participated in the Autumn Business School, over the period of three years. The authors invited all participating companies in the Autumn Business School project, as of 2016 for an in-depth interview. Four of the 5 companies agreed to have such an interview. Even though the number of companies is quite limited, the talks resulted in a deeper understanding of the usefulness of certain projects and what companies do expect from students and the results that were in it for them in the specific project that was done for them. As written above, this study revolves around the added value for companies to be involved in this type of universitybusiness cooperation. Added value is defined as: new knowledge, new insights and newly created business opportunities for the participating company.

The information was collected by means of semi-structured interviews with the entrepreneur/owner of the company involved. The reason to use this method was that it may be not so clear what the exact added value was and it may need some additional questioning before the necessary information can be found. Since this study is somewhat exploratory, semi-structured interviews give the best possible opportunity to identify different types of added value. The themes of the interview questions were about whether new knowledge was generated, new insights were found, new opportunities were created and in general, how much the companies valued the entire project and its outcomes.

\section{Results of the interviews}

All interviewed companies indicated the work that was done for them by the students was helping to increase their knowledge of the market and gave them insight in the specific ways of doing business in these countries, for example:

Verhelderend is de hernieuwde vaststelling dat je je bewust moet zijn van cultuurverschillen omdat deze zakendoen beïnvloeden [I realized again that I have to be aware of cultural differences that influence business] 
Conference proceedings $2^{\text {nd }}$ and $3^{\text {rd }}$ Regional Innovation \& Entrepreneurship Conference

Wij hebben inzicht gekregen in welke mogelijkheden er voor onze producten in de Russische markt zijn en hoe we in Rusland in praktijk het beste aan de slag zouden kunnen gaan [We got insight in the opportunities for our product on the Russian market as well as how to start our operations there].

Our business is quite specific, we did some work on construction market related questions before and needed some more answers about the Russian market. One thing we surely understood is that how extremely important social capital is on the Russian market.

Even though all companies reported to have gained valuable insights, when talking about the creation of actual business opportunities, the picture is a bit different. One company reported to be actively negotiating with two foreign partners, one company is in the stage of opening negotiations (the project helping this specific company finished only three months ago, which may explain the current stage) and two other companies indicated to have found no opportunities for now to sell their product. For example:

At the moment we focus on a different market, we have some concrete demand over there and since we are only a medium sized company, we can only do so much at a time.

When asked for the overall results of the project for the companies and how they valued it, three of the four interviewed companies answered that they considered the project result very satisfactory, and one considered the results to be good.

On the topic of cooperating with students in this project, not all companies reported that they were always pleased. One company specifically reported that they were generally not happy with the behaviour of the students, which they considered to be rather unprofessional:

Ik vond de studenten gemiddeld maar matig enthousiast, met enkele uitzonderingen daargelaten. Veelal studentikoze houding voor wat betreft aandacht en opkomst bij bijeenkomsten en inzet van eigen talent [I considered the students on average to be only little enthusiastic for the project, with a few notable exceptions. Often quite a strong adolescent behaviour in relation to attention during and showing up at meetings as well as little enthusiasm to use their talents to get the best out of it]. 
Conference proceedings $2^{\text {nd }}$ and $3^{\text {rd }}$ Regional Innovation \& Entrepreneurship Conference Another company reported more positive behaviour, as they were impressed by the ability of the students to operate so independently and deliver nonetheless useful results:

De studenten hebben veelal zelfstandig gewerkt en de samenwerking met Saxion is prima verlopen. Dat er op dit moment geen goede mogelijkheden zijn ligt aan de marktomstandigheden en kan niemand kwalijk genomen worden. [The students mostly worked independently and the cooperation with Saxion worked fine. The fact that there are no good opportunities at this moment is because of the market circumstances and can't be blamed on anyone].

As far as recommendations for improvement of the project, three entrepreneurs suggested to have the final presentation face to face and not via Skype, as they considered the distance to be detrimental for the full understanding of the presentation. One company mentioned that they had also quite big problems in understanding the presentation at all, because of recurring technical issues with the connection.

All interviewed companies told that they would recommend colleagues to participate in this type of projects. Some companies were more outspoken about it than others, but in general the results were quite positive. One of the company remarked for example:

It is important to realize that it will take you as company also a significant amount of time to invest in this project. We have a very dynamic and busy environment, so we usually don't like to read big reports. I understood we should have paid more attention to details. This is what I would recommend others: If you participate, do it only if you can free up enough time. You will get something useful, but it is going to cost you time.

Another company specifically added:

I liked the fact that I got two reports, from two different groups.

One report was better than the other, but both consisted of valuable insights. This is what I like and would recommend to others: you will get different perspectives, which makes you think about your own assumptions. 
Conference proceedings $2^{\text {nd }}$ and $3^{\text {rd }}$ Regional Innovation \& Entrepreneurship Conference

\section{Conclusion and recommendations}

As far as the companies are concerned, the cooperation with students in the Autumn School was successful. It gave them insight in their way of doing business, their cultural assumptions and helped to improve the cultural awareness. In terms of the creation of actual business opportunities, the picture is a bit more mixed. Companies who reported not to have gotten more opportunities, blamed it on the current bad economic circumstances in Russia, or bigger attractiveness of different markets. Others reported to be negotiating with partners abroad. Student behaviour during the project (1 company) and the non-face to face final presentations ( 3 companies) were mentioned as being of detrimental influence on the project.

One of the recommendations is to monitor the behaviour of the students in future projects and train them in business etiquette, in order to minimize potential disappointment for the client.

Another recommendation is to have the design of the future editions of the project in such way that the final presentation for the company is as much as possible faceto-face for the entire team.

\section{References}

Bazen, J. C., \& Petrova, I. S. (2013). International cooperation between The Netherlands \& Russia: Case study of Dutch-Russian Autumn Business School as example of modernizing Russia's higher education. Paper presented at the Vocational education, science and innovation in the $21 \mathrm{st}$ century, St. Petersburg.

Bazen, J. C., \& Petrova, I. S. (2014). Opening the Russian Market: Measuring the effect of short term international student exchanges in the field of entrepreneurship. Paper presented at the Catching up new ideas: Management, Economics and Law 2014, Kaunas.

Davey, T., Baaken, T., Galan Muros, V., \& Meerman, A. (2011). Final Report Study on the cooperation between Higher Education Institutions and public and private organisations in Europe. Retrieved from Münster:

Edmondson, G., Valigra, L., Kenward, M., Hudson, R. L., \& Belfield, H. (2012). MAKING INDUSTRY-UNIVERSITY PARTNERSHIPS WORK. Retrieved from Brussels:

Etzkowitz, H., \& Leydesdorff, L. (2000). The dynamics of innovation: from National Systems and "Mode 2" to a Triple Helix of university-industry- 
Conference proceedings $2^{\text {nd }}$ and $3^{\text {rd }}$ Regional Innovation \& Entrepreneurship Conference government relations. Research Policy, 29(2), 109-123. doi:10.1016/s0048-7333(99)00055-4

Johnson, D. W., Johnson, R. T., \& Smith, K. (2007). The state of cooperative learning in postsecondary and professional settings. Educational Psychology Review, 19(1), 15-29. doi:10.1007/s10648-006-9038-8

Kyndt, E., Raes, E., Lismont, B., Timmers, F., Cascallar, E., \& Dochy, F. (2013). A meta-analysis of the effects of face-to-face cooperative learning. Do recent studies falsify or verify earlier findings? Educational Research Review, 10, 133-149. doi:10.1016/j.edurev.2013.02.002

Pavlin, S., Kesting, T., \& Baaken, T. (2016). An Integrative View on Higher Education and University-Business Cooperation in the Light of Academic Entrepreneurship. European Journal of Education, 51(1), 3-9. doi:10.1111/ejed.12168 